Revista Brasileira de Cartografia

ISSN 1808-0936 | https://doi.org/10.14393/revbrascartogr

Sociedade Brasileira de Cartografia, Geodésia, Fotogrametria e Sensoriamento Remoto

\title{
Cartografia Geomorfológica Aplicada à Bacia Hidrográfica do Ribeirão do Brejão, Município de Nova Ponte (MG): Indicativos da Evolução do Relevo e Contribuições ao Planejamento
}

\author{
Geomorphological Mapping Applicated to Ribeirão do Brejão Hydrographic Basin, \\ Municipality of Nova Ponte (MG): Indicators of the Evolution of Relief and Contributions \\ to Planning
}

Bruno Ferreira da Silva ${ }^{1}$, Alan Silveira ${ }^{2}$ e Marília Inês Mendes Barbosa ${ }^{3}$

1 Universidade Federal de Uberlândia, Instituto de Geografia, Monte Carmelo, Brasil. brunof_silva1998@hotmail.com. ORCID: https://orcid.org/0000-0001-9323-6183

2 Universidade Federal de Uberlândia, Instituto de Geografia, Monte Carmelo, Brasil. alan.silveira@ufu.br.

ORCID: https://orcid.org/0000-0001-7144-8038

3 Universidade Federal de Uberlândia, Instituto de Geografia, Monte Carmelo, Brasil. mariliabarbosa@ufu.br.

ORCID: https://orcid.org/0000-0001-6169-5430

Recebido: 03.2020 | Aceito: 06.2020

\begin{abstract}
Resumo: Este trabalho consistiu na investigação das características geomorfológicas da bacia hidrográfica do Ribeirão do Brejão, no município de Nova Ponte (MG), posicionada nos Planaltos e Chapadas da borda nordeste da Bacia Sedimentar do Paraná. Parte-se do pressuposto que o uso de técnicas da cartografia geomorfológica de detalhe contribuem com informações ao planejamento territorial/ambiental e com indicativos da evolução do relevo. Os elementos geomorfológicos que compõem a bacia foram mapeados por meio de fotointerpretação no software ArcGIS que possibilitou a elaboração da carta Geomorfológica na escala 1:25.000. Ainda, foi proposto a confecção da carta de Energia do Relevo que possibilita zonear as áreas mais suscetíveis aos processos morfodinâmicos. Uma análise integrada destes documentos cartográficos permitiu uma caracterização detalhada dos elementos topográficos, assim como os tipos de vertentes e topos, a ação dos cursos d'água e o modelado antrópico, que corroboram com uma interpretação na dinâmica natural e a interferência antrópica na bacia. Em campo, identificou-se a ocorrência de feições erosivas e represamentos destinados à irrigação que possibilitaram interpretar um avanço de feições denudativas no sentido da Alta Bacia, porção com menor potencial morfogenético, porém, que apresenta elevada interferência antrópica. Ainda, evidenciaram-se rupturas topográficas que apresentam perfis de alteração com a presença de stone lines que pavimentam os basaltos da Formação Serra Geral, permitindo inferir uma condição paleoclimática associada a processos pretéritos de aplainamento.
\end{abstract}

Palavras-chave: Caracterização Geomorfológica. Energia do Relevo. Superfícies de Aplainamento. Nova Ponte (MG). Ribeirão do Brejão.

Abstract: This paper presents a geomorphological investigation of the characteristics of the Ribeirão do Brejão
hydrographic basin, in Nova Ponte (MG), located at the Plateaus and Tablelands of the northeast edge of the Paraná
Sedimentary Basin. It is assumed that the application of detailed geomorphological mapping techniques contributes
to data for territorial/environmental planning, as well as indicators of the evolution of relief. The geomorphological
elements of this basin were mapped using photointerpretation in ArcGIS software and enabled the elaboration of the
Geomorphological map at a scale of $1: 25,000$. Furthermore, in this study, the production of the Relief Energy map
was proposed, which permits to identify the susceptible areas to morphodynamic processes. An integrated analysis of
these cartographic products allows obtaining a detail characterization of the topographic elements, as well as sorts of
slopes and summits, the action of watercourses and anthropic activities, which corroborate with an interpretation of
the natural dynamics and the anthropic interferences in this basin. Due to fieldworks, it was observed erosions and
impoundments for irrigation, which grant the analysis of an advance of the denudational forms towards the Upper
Basin, the sector with less morphogenetic potential, however, which presents intense anthropic interference. Besides,
it is possible to recognize on profiles a pavement over the volcanic flows of the Serra Geral, in which the stone lines
can suggest a paleoclimatic condition associated with the past slope flattening processes. Keywords: Geomorphological Characterization. Relief Energy. Slope Flattening. Nova Ponte (MG). Ribeirão do Brejão. 


\section{INTRODUÇÃO}

O objetivo de uma carta geomorfológica de detalhe é fornecer uma descrição racional de todos os elementos do relevo, indicam Sato e Lupinacci (2019), ao referenciar o trabalho de Tricart (1965). Para as autoras, trata-se de um processo que exige reflexão e conhecimento sobre o objeto que será representado e também sobre o contexto físico no qual ele se insere. Neste sentido, a cartografia geomorfológica se constitui em um importante instrumento na espacialização dos fatos geomorfológicos, permitindo representar a gênese das formas do relevo e suas relações com a estrutura e processos, bem como com a própria dinâmica dos processos (CASSETI, 2007).

Diferentemente dos outros documentos cartográficos, o mapeamento geomorfológico baseia-se na descrição qualitativa do relevo, tanto das características quanto dos processos atuantes, sendo representado por pontos, linhas e polígonos (OTTO; GUSTAVSSON; GEILHAUSEN, 2011). A representação dos elementos que descrevem as formas, os processos e as características físicas, expressos pela legenda do mapa, dependem da escala e da configuração do modelado analisado, estando passível de adaptações conforme a necessidade (VERSTAPPEN, 2011). A escala ainda deve ser configurada a partir da proposta do mapeamento e das condições da área de estudo, permitindo a criação de novas simbologias para satisfazer o elemento descrito (OTTO; GUSTAVSSON; GEILHAUSEN, 2011), visto que a escala implica tanto na elaboração quanto no resultado desejado do mapeamento geomorfológico (CUNHA; QUEIROZ, 2012).

O uso da cartografia geomorfológica como instrumento de compreensão das formas, gênese e cronologia do relevo é bastante difundido, já que possibilita identificar complicações territoriais, sejam de origem antrópica ou natural (SILVEIRA; LUPINACCI, 2017). A interpretação do relevo é uma ferramenta de identificação e correlação da dinâmica dos processos atuais e pretéritos (ROSS, 1991), colaborando também para trabalhos aplicados de zoneamentos (SILVA; SILVA, 2012). Esta interpretação consiste em uma análise sistêmica que permite compreender a interação do relevo com o clima, a geologia, a vegetação e a ação antrópica (ANDRADE; CUNHA; SOUZA, 2010).

Com referência à União Geográfica Internacional (UGI), Tricart (1965) indica que o mapa geomorfológico deve conter informações morfométricas, morfográficas, morfogenéticas e cronológicas. Casseti (2005) argumenta que para evitar a sobrecarga de informações na carta geomorfológica, os dados morfométricos podem ser representados a parte, em uma apresentação cartográfica específica, facilitando sua leitura. A morfometria do relevo consiste na quantificação das feições da superfície terrestre a partir de parâmetros como a declividade, a dissecação, a hipsometria, entre outros.

Acerca da morfometria do relevo, tem-se a carta de Energia do Relevo (MENDES, 1993) que resulta da integração das cartas de Declividade, de Dissecação Horizontal e de Dissecação Vertical (CUNHA; MENDES; SANCHEZ, 2003). Tal proposta de mapeamento (MENDES, 1993), faz uso das técnicas de Spiridonov (1981) e tem objetivo similar ao documento de dissecação geral do relevo proposta por Hubp (1988). Com esta carta, torna-se possível obter classes de energia do relevo que permitem apontar qualitativamente as áreas mais suscetíveis à ocorrência de processos morfodinâmicos, representando uma maior fragilidade natural aos processos denudativos (SILVEIRA; CUNHA, 2011).

Uma análise conjunta da carta Geomorfológica e da carta de Energia do Relevo possibilita compreender a dinâmica entre o relevo e os processos atuantes, tendo em vista a interferência da litologia, o desnível topográfico e a atuação das drenagens na potencialidade dos processos erosivos (CUNHA; PINTON, 2013). Considerando a carência de pesquisas com fins à interpretação dos processos morfodinâmicos e da dinâmica evolutiva do relevo em escala de detalhe para a região do Triângulo Mineiro e Alto Paranaíba (MG), propôs-se a elaboração da carta Geomorfológica e da carta de Energia do Relevo para a bacia hidrográfica do Ribeirão do Brejão, a qual se posiciona na borda nordeste da Bacia Sedimentar do Paraná.

A referida bacia hidrográfica possui área de $73,36 \mathrm{~km}^{2}$ e situa-se no município de Nova Ponte (MG), como pode ser visto na Figura 1. Está posicionada sobre os Planaltos e Chapadas da Bacia Sedimentar do Paraná (ROSS, 1985) e caracteriza-se pelo clima Tropical Semi-Úmido com os seguintes aspectos: quente ao longo do ano com quatro a cinco meses secos; temperatura média anual entre $22^{\circ} \mathrm{C}$ a $26^{\circ} \mathrm{C}$; pluviosidade média anual entre 1100 a $1750 \mathrm{~mm}$ (NOVAIS, 2011). 
Figura 1 - Mapa de localização da área de estudo.

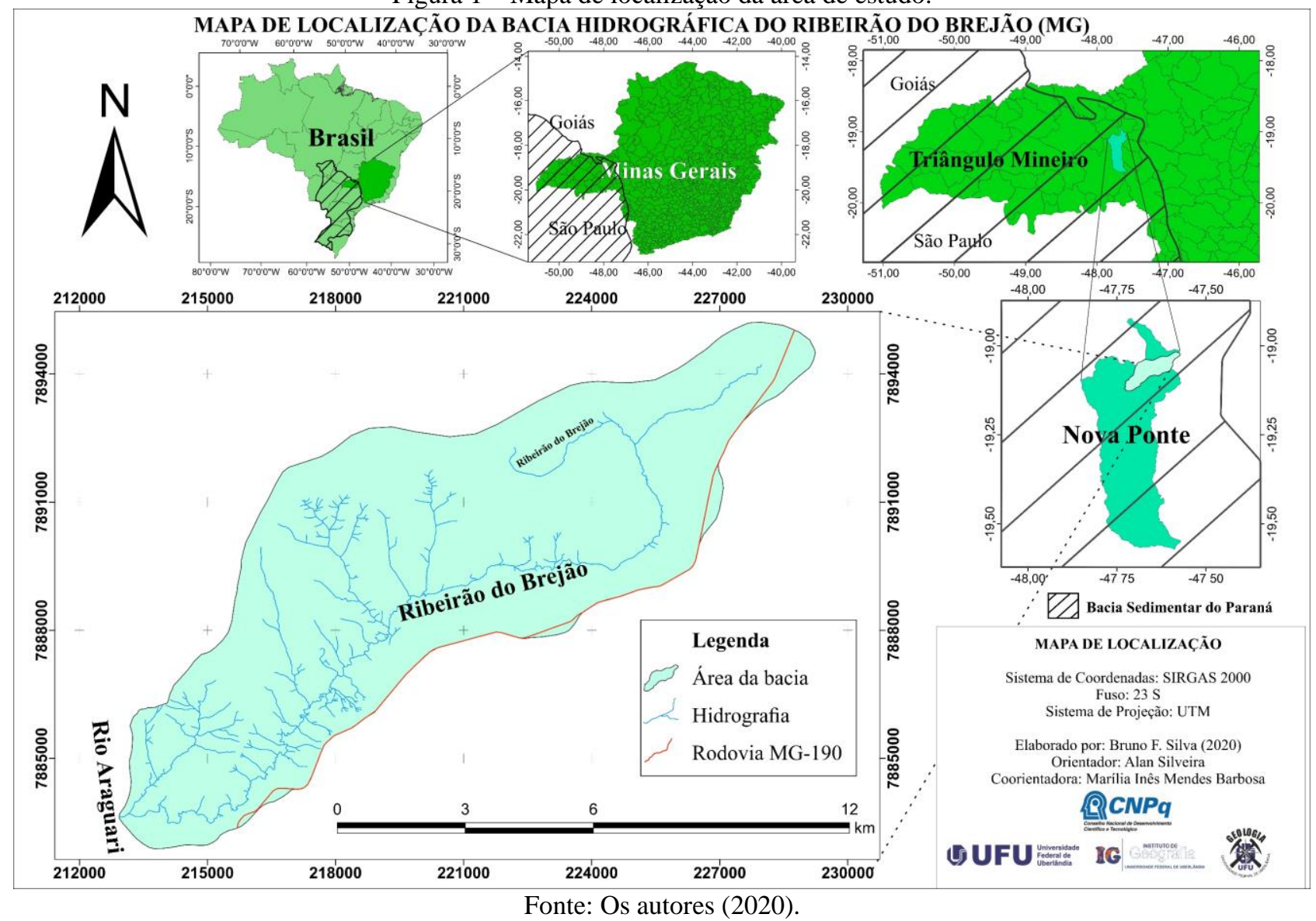

Mediante trabalhos de campo para reconhecimento da área, notou-se a ocorrência de represamentos de canais próximos à nascente, assim como diversas canalizações antrópicas para o abastecimento de represas destinadas à irrigação. Além disso, tem-se a ocorrência de inúmeras feições erosivas distribuídas ao longo da bacia, com maior incidência nos setores mais próximos à foz, em virtude das diferentes características geológico-geomorfológicas, as quais resultam em distintos contextos morfodinâmicos. No entanto, há uma intensa interferência antrópica na Alta Bacia que pode proporcionar uma fragilidade na dinâmica natural e, consequentemente, promover uma ascensão destas feições erosivas para este setor.

Desta forma, o trabalho tem o objetivo de compreender a dinâmica geomorfológica na bacia eleita para estudo, a partir de instrumentos da cartografia geomorfológica de detalhe, neste caso, por meio das cartas de Energia do Relevo e Geomorfológica. Considera-se que o uso destes documentos permitem uma compreensão da atual dinâmica geomorfológica, com o fornecimento de dados e produtos para o planejamento e gestão territorial/ambiental, bem como colaboram com indicativos da evolução geomorfológica da bacia hidrográfica selecionada para estudo. Além do mencionado contexto antrópico na referida área, destaca-se também o seu contexto geológico-geomorfológico, associado regionalmente aos Planaltos e Chapadas da Bacia Sedimentar do Paraná (ROSS, 1985), que passa a ser abordado no continuo do texto.

\section{CONTEXTO GEOLÓGICO-GEOMORFOLÓGICO DA ÁREA DE ESTUDO}

A Bacia Sedimentar do Paraná, de forma oval e contida integralmente na placa Sul-Americana, possui uma área superior a $1.500 .000 \mathrm{~km}^{2}$ que abrange o Brasil meridional, o norte do Uruguai, as porções nordestes da Argentina e o Paraguai oriental (MILANI, 2004). Acerca da formação desta bacia, tem-se os processos geológicos associados ao Neo-Ordoviciano e o Neo-Cretáceo devido à sucessão sedimentar-magmática, configurando em um dos maiores eventos geológicos relativos à fragmentação do pretérito continente Gondwana junto ao desenvolvimento do Oceano Atlântico (MILANI, 2004; BASILICI; SGARBI; FÜHR, 2012).

Este evento geotectônico propiciou um intenso vulcanismo que deu origem à Formação Serra Geral, 
pertencente ao Grupo São Bento (Cretáceo Inferior). Por conta do resfriamento dos basaltos do Serra Geral e uma compensação isostática exercida na crosta continental, teve-se a possibilidade da deposição de sedimentos que resultou na gênese da Sub-Bacia Bauru (Cretáceo Superior) (BASILICI; SGARBI; FÜHR, 2012). Pertencente à Sub-Bacia Bauru, tem-se a Formação Marília (Cretáceo Superior - Maastrichtiano) que possui três membros, Serra da Galga, Ponte Alta e Echaporã, porém não diferenciados no mapeamento da CODEMIG (2017). Ainda, segundo o relatório técnico da CODEMIG (2017), para a área de estudo e proximidades há uma escassez de bons afloramentos da Formação Marília.

King (1956) buscou reconhecer os eventos geomorfológicos responsáveis por esculpir o relevo brasileiro oriental, reconhecendo ciclos geomorfológicos associados a diferentes contextos de aplainamento. Os distintos níveis das coberturas que revestem o Brasil são resultados dos variados estágios de aplainamento ao longo do tempo geológico (BRAUN, 1971).

O Soerguimento do continente durante o Ciclo Sul-Americano, no início do Cretáceo Superior, está associado a um ciclo erosivo que propiciou uma extensa superfície (BRAUN, 1971). Para o autor, este aplainamento foi posteriormente erodido, resultando na presença de alguns testemunhos que marcam esse nível de aplainamento pretérito e que configura o atual relevo brasileiro. Quanto aos remanescentes da Superfície Sul-Americana, denominadas Superfície Sul-Americana I e Superfície Sul-Americana II, são caracterizados por elevados teores de ferro em meio a um embasamento de litologia variada, expressos pelos pacotes lateríticos, em virtude da exposição deste material a longos períodos de oscilação do nível freático e que estão comumente recobertos por horizontes arenosos (BRAUN, 1971; VALADÃO, 2009).

O Soerguimento do Alto Paranaíba está associado com os processos erosivos que atuaram nos limites da Sub-Bacia Bauru, mediante esta reestruturação tectônica do Paleogeno/Neogeno (SEER; MORAES, 2017). Segundo Braun (1971), os chapadões da Mata da Corda, que teve sua gênese durante o Soerguimento do Alto Paranaíba, situam-se na porção oeste de Minas, com cotas entre 1000 a 1150 metros, com inclinação suave sentido nordeste e em que há um nivelamento com os testemunhos da Serra do Salitre, Chapadão de Ferro e Serra da Canastra, com elevações em torno de 1300 metros, com uma diferença máxima de 200 metros para as superfícies em pontos distantes (BRAUN, 1971).

Segundo Carvalho et al. (2017), a chapada Uberaba-Uberlândia (área da bacia do rio Claro), que também se prolonga entre Uberaba e Nova Ponte, é resultado de processos tectônicos e erosivos pretéritos associados a aplainamento Sul-Americano e a lateritização das coberturas. A bacia do Ribeirão do Brejão possui também, em seus topos aplainados, cotas altimétricas equivalentes e espessos pacotes lateritizados semelhantes àqueles da chapada Uberaba-Uberlândia. Destaca-se que a distância entre as nascentes do Ribeirão do Brejão e do Rio Claro, ambos afluentes do Rio Araguari, é de apenas $70 \mathrm{~km}$ e possuem cotas altimétricas em torno de 1010 metros. Esta chapada é classificada como Planalto Tabular das Unidades Geomorfológicas do Triângulo Mineiro, caracterizando-se como os compartimentos de relevo mais elevados da região, com altitudes entre 950 e 1050 metros. (CARVALHO et al., 2017).

A partir da fotointerpretação e dos dados coletados em trabalhos de campo, junto às informações do mapeamento geológico CODEMIG (2017), elaborou-se um bloco diagrama para a área de estudo (Figura 2), que visa facilitar a compreensão da relação entre contexto geológico e o comportamento do relevo.

Figura 2 - Bloco Diagrama da bacia hidrográfica do Ribeirão do Brejão.

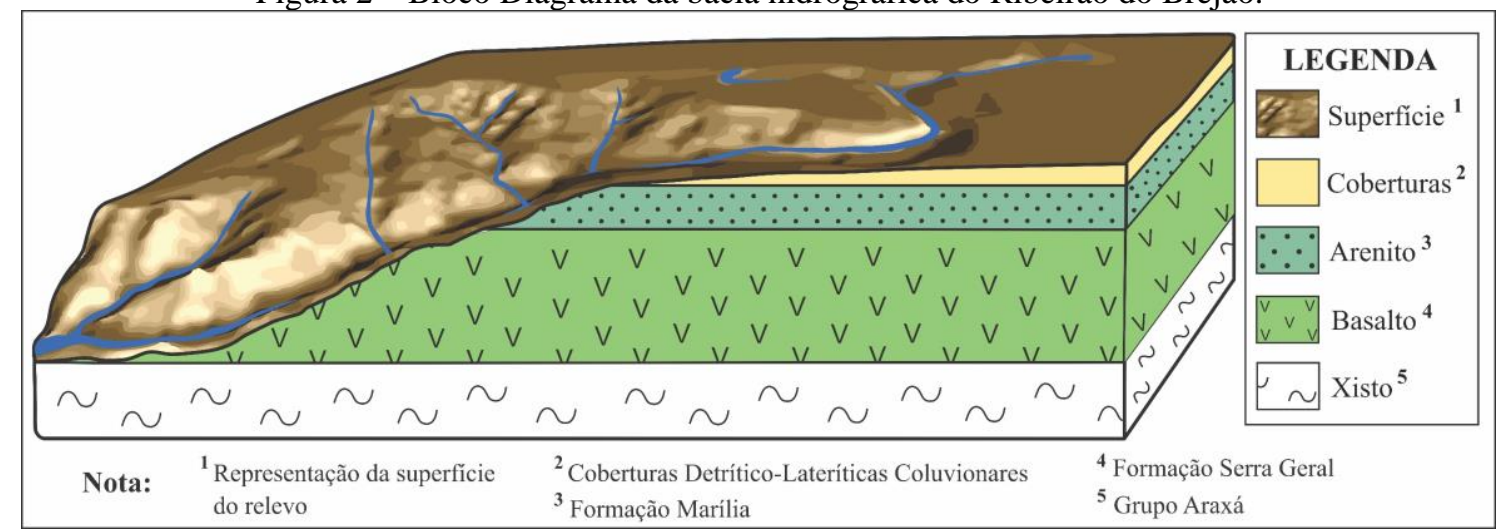

Fonte: Os autores (2020). 
As características litológicas das unidades apresentadas no bloco diagrama foram extraídas do relatório técnico da CODEMIG (2017). Segundo o relatório citado anteriormente, o Grupo Araxá (Neoproterozoico), pertencente à Faixa de Dobramentos Brasília e unidade de embasamento, é composto por muscovita xisto, por vezes associado com biotita, de granulação fina e de coloração cinza clara a cinza esverdeada. A Formação Serra Geral possui basaltos, de granulação fina e textura ofítica, constituídos por piroxênio e microfenocristais de plagioclásio, além de vidro vulcânico. A Formação Marília possui arenitos de fino a médio, imaturos, vermelhos e ferruginosos, assim como conglomerados clasto-suportados quartzosos. As Coberturas DetríticoLateríticas Coluvionares, posicionadas nos topos aplainados, são constituídas por grãos quartzo arenosos, amarelados a avermelhados, esféricos e subarredondados, com associação de couraças lateríticas ferruginosas.

Quanto à cobertura pedológica, predominam os Latossolos Amarelos Distróficos e Latossolos Vermelhos Acriférricos, com presença de Neossolos Litólicos Distróficos, porém estes mais restritos (MOTTA; BARUQUI; SANTOS, 2004). Em campo, notou-se a predominância dos Latossolos nos relevos tabulares mediante reduzidas declividades, expressos por espessos perfis pedogenizados. Em contrapartida, nas porções mais denudadas referentes aos planaltos dissecados da bacia hidrográfica, tem-se a ocorrência de Cambissolos e Neossolos. Como pode ser visualizado no bloco diagrama, em cotas altimétricas mais elevadas registram-se feições suavizadas, configurando os planaltos tabulares com a presença de áreas agricultáveis. Já quando se dirige sentido a foz, tem-se uma dissecação mais pronunciada nestes planaltos, caracterizando a borda erosiva dos planaltos tabulares.

Em síntese, o diferente comportamento do relevo quanto à dissecação dos planaltos está diretamente associado com a variação litológica ao longo da área de estudo. Nas porções correspondentes aos basaltos da Formação Serra Geral há um maior entalhamento dos vales, enquanto nas áreas de Coberturas e da Formação Marília há uma suavização no relevo. Ressalta-se que o posicionamento da bacia hidrográfica do Ribeirão do Brejão na borda da Bacia Sedimentar do Paraná, em porções aplainadas do Brasil Central, neste caso em borda de chapada, configura a complexidade na dinâmica dos processos morfogenéticos e na evolução do relevo. $\mathrm{O}$ contexto de borda de bacia está associado com o avanço dos processos denudativos sentido montante, ou seja, com a erosão regressiva instalada por canais fluviais que buscam ajustes em seus perfis de equilíbrio. Nesta perspectiva, um dos canais fluviais que dissecam as bordas das referidas chapadas do Brasil Central, é o Ribeirão do Brejão.

\section{MATERIAL E MÉTODO}

Propôs-se a edição da Base Cartográfica e dos demais documentos cartográficos a partir do software ArcGIS 10.5 e de softwares gráficos a fim de melhorar o produto dos mapeamentos gerados, como o CorelDRAW 2017. As cartas a seguir são resultados de compilação de dados cartográficos e de trabalhos em campo, visto que o último é essencial para a verificação das informações espaciais representadas.

\subsection{Carta de Energia do Relevo}

No caso da carta de Energia do Relevo, utilizou-se de base cartográfica a Carta Topográfica do IBGE pertencente à Folha Nova Ponte (MI-2489-2), de 2007, com escala de 1:50.000 e equidistância das curvas de nível de $20 \mathrm{~m}$. Todos os dados extraídos, manipulados e compilados foram feitos no ArcGIS 10.5.

A elaboração da carta de Energia do Relevo advém da compilação de dados quantitativos de cartas morfométricas, segundo a proposta de Mendes (1993). O procedimento consiste na extração dos dados obtidos a partir dos seguintes documentos: da carta de Declividade (DE BIASI, 1970, 1992), que representa quantitativamente, em porcentagem, a inclinação das vertentes; da carta de Dissecação Horizontal (SPIRIDONOV, 1981; com adaptações de MAURO et al., 1991; e a proposta automática de FERREIRA et al., 2014), que quantifica a distância que separa os talvegues das linhas de cumeada; e da carta de Dissecação Vertical (SPIRIDONOV, 1981; e a proposta automática de FERREIRA et al., 2015), que quantifica a altitude relativa entre a linha de cumeada e o talvegue. As cartas morfométricas mencionadas foram já elaboradas para a área de estudo em trabalhos anteriores de Silva, Silveira e Barbosa (2019a, 2019b), as quais contribuíram com dados para a organização da carta de Energia do Relevo. 
Como produto de integração das informações obtidas por meio das cartas morfométricas citadas, configura-se a carta de Energia do Relevo, espacializando o potencial morfométrico para o desencadeamento de processos morfológicos (SILVEIRA; CUNHA, 2011). Com esses três documentos cartográficos gerados a partir do software ArcGIS, importaram-se todas as shapefiles respectivas às classes de cada carta morfométrica e hierarquizaram-se os dados na ordem proposta por Mendes (1993). Desta forma, obteve-se a carta de Energia do Relevo, seguindo as classes adotadas para este trabalho e com as respectivas cores escolhidas (Quadro 1).

Quadro 1 - Classes de energia do relevo e os critérios de classificação.

\begin{tabular}{|c|c|c|c|}
\hline Energia do relevo & Declividade (\%) & Dissecação horizontal (m) & Dissecação vertical (m) \\
\hline \multirow{3}{*}{ Muito forte } & $\geq 40$ & $<50 ; 50 \mathrm{~F} 800 ; \geq 800$ & $\geq 100 ; 20 \mathrm{~F} 100 ;<20$ \\
\hline & $3 \mathrm{~F} 40 ;<3$ & $<50$ & $\geq 100 ; 20 \mathrm{~F} 100 ;<20$ \\
\hline & $3 \mathrm{~F} 40 ;<3$ & $50 \mathrm{~F} 800 ; \geq 800$ & $\geq 100$ \\
\hline \multirow{3}{*}{ Forte } & $24 \mathrm{~F} 40$ & $50 \mathrm{~F} 800 ; \geq 800$ & $20 \mathrm{~F} 100 ;<20$ \\
\hline & $3 \mathrm{~F} 24 ;<3$ & $50 \mathrm{~F} 100$ & $20 \mathrm{~F} 100 ;<20$ \\
\hline & $3+24 ;<3$ & $100 \mathrm{~F} 800 ; \geq 800$ & $80 \mathrm{~F} 100$ \\
\hline \multirow{3}{*}{ Mediamente forte } & $12 \mathrm{~F} 24$ & $100 \mathrm{~F} 800 ; \geq 800$ & $20 \mathrm{~F} 80 ;<20$ \\
\hline & $3 \mathrm{~F} 12 ;<3$ & $100 \mathrm{~F} 200$ & $20 \mathrm{~F} 80 ;<20$ \\
\hline & $3 \mathrm{~F} 12 ;<3$ & $200 \mathrm{~F} 800 ; \geq 800$ & $60 \mathrm{~F} 80$ \\
\hline \multirow{3}{*}{ Média } & $6 \mathrm{~F} 12$ & $200 \mathrm{~F} 800 ; \geq 800$ & $20 \mathrm{~F} 60 ;<20$ \\
\hline & $3 \mathrm{~F} 6 ;<3$ & $200 \mathrm{~F} 400$ & $20 \mathrm{H} 60 ;<20$ \\
\hline & $3 \mathrm{H} 6 ;<3$ & $400 \mathrm{~F} 800 ; \geq 800$ & $40 \mathrm{H} 60$ \\
\hline \multirow{3}{*}{ Fraca } & $3 \mathrm{~F} 6$ & $400 \mathrm{~F} 800 ; \geq 800$ & $20 \mathrm{~F} 40 ;<20$ \\
\hline & $<3$ & $400 \mathrm{~F} 800$ & $20 \mathrm{~F} 40 ;<20$ \\
\hline & $<3$ & $\geq 800$ & $20 \mathrm{~F} 40$ \\
\hline Muito fraca & $<3$ & $\geq 800$ & $<20$ \\
\hline
\end{tabular}

Fonte: Os autores (2020).

\subsection{Carta Geomorfológica}

Na carta Geomorfológica, pretendeu-se cartografar os dados referentes à morfografia e à morfogênese, sendo que as condicionantes morfométricas foram representadas nas cartas morfométricas, integradas na carta de Energia do Relevo. Os procedimentos de fotointerpretação e definição da simbologia foram apoiados em Tricart (1965). No entanto, esta não contempla símbolos para as formas de vertentes, sendo necessário adaptar simbologias propostas por Verstappen e Zuidam (1975), dada a importância dessas na interpretação do quadro geomorfológico. Além disso, também foram adotadas as recomendações propostas por Paschoal, Conceição e Cunha (2010), para confecção de simbologias geomorfológicas no software ArcGIS. Assim, a carta Geomorfológica foi produzida no ArcGIS 10.5 a partir de fotointerpretação do Ortomosaico do IBGE, de 2005, pertencente à folha SE.-Y-C-I-2-NE e articulação MI-2489-2-NE, com escala 1:25.000. A integração de informações de 2019 por meio do Google Earth Pro e trabalhos de campo também corroboraram para uma melhor perspectiva do quadro atual.

As cartas geomorfológicas de detalhe fornecem subsídios para uma análise minuciosa de todos os elementos que compõem o relevo, sejam eles naturais ou derivados da ação antrópica, que são expressos em formas de símbolos e cores que se sobrepõem, o que lhe confere grande complexidade ao gerá-las. Com a fotointerpretação geomorfológica da área e a elaboração de todas as simbologias, tornou-se possível obter quatro categorias principais dos elementos representados na carta Geomorfológica (Figura 3), que compreendem: as formas das vertentes e interflúvios (1), os dados topográficos (2), a ação das águas correntes (3) e os modelados antrópicos (4). Tais simbologias serão importantes para a interpretação das figuras oriundas da carta Geomorfológica, as quais serão apresentadas na sequência textual no item Resultados e Discussão.

Figura 3 - Elementos representados na carta Geomorfológica. 


\begin{tabular}{|c|c|c|}
\hline $\begin{array}{l}\text { 1. FORMAS DE VERTENTES E INTERFLÚVIOS } \\
1.1 \text { - Formas de topos e vertentes } \\
\text { C Convexo } \\
\text { Retilincavo / Tabular } \\
\text { 1.2 - Formas Denudativas } \\
\text { S Rulcos } \\
\text { R Ruptura topográfica aguda } \\
\text { R Ruptara topográfica suave }\end{array}$ & 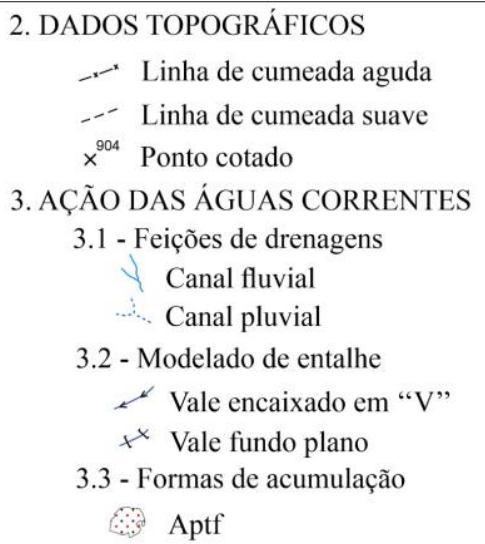 & 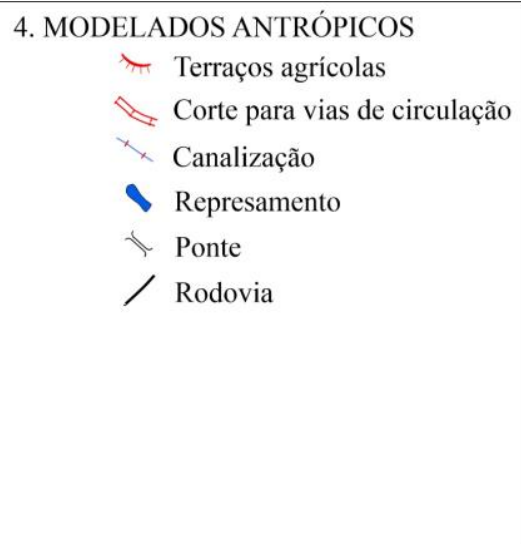 \\
\hline
\end{tabular}

Fonte: Os autores (2020).

\section{RESULTADOS E DISCUSSÃO}

A fim de apresentar os resultados e de facilitar a sua discussão, mediante a integração dos dados morfométricos, geomorfológicos e geológicos foi possível compartimentar a área de estudo em três setores: Alta, Média e Baixa Bacia, apresentados na Figura 4.

Figura 4 - Compartimentos da área de estudo.

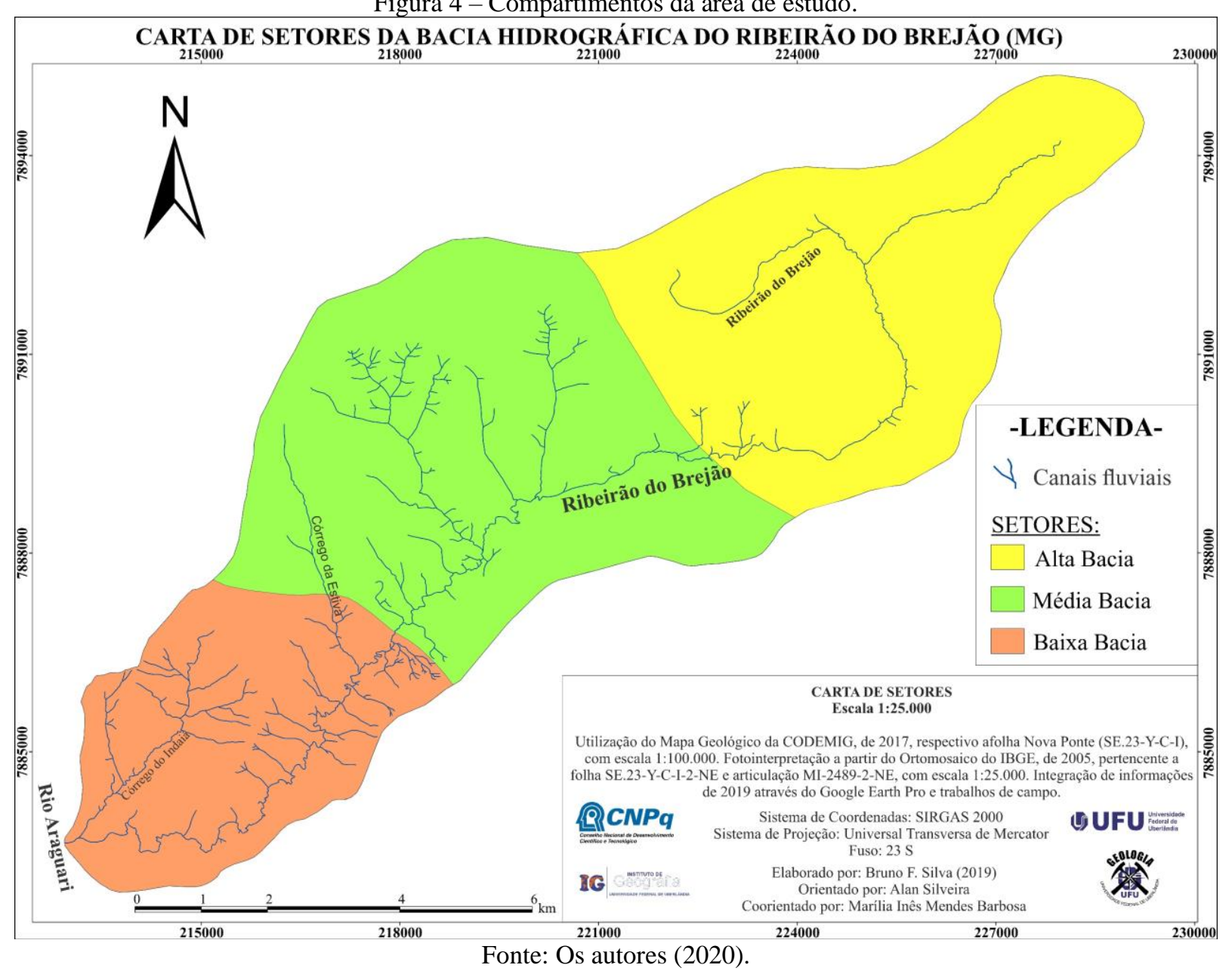

A partir dos procedimentos técnicos cartográficos descritos no item Material e Método foi possível obter a carta de Energia do Relevo e a carta Geomorfológica, ilustradas nas Figuras 5 e 6, respectivamente. Informa-se que os elementos geomorfológicos representados na Figura 6, correspondem as mesmas simbologias apresentadas na Figura 3.

Figura 5 - Carta de Energia do Relevo. 


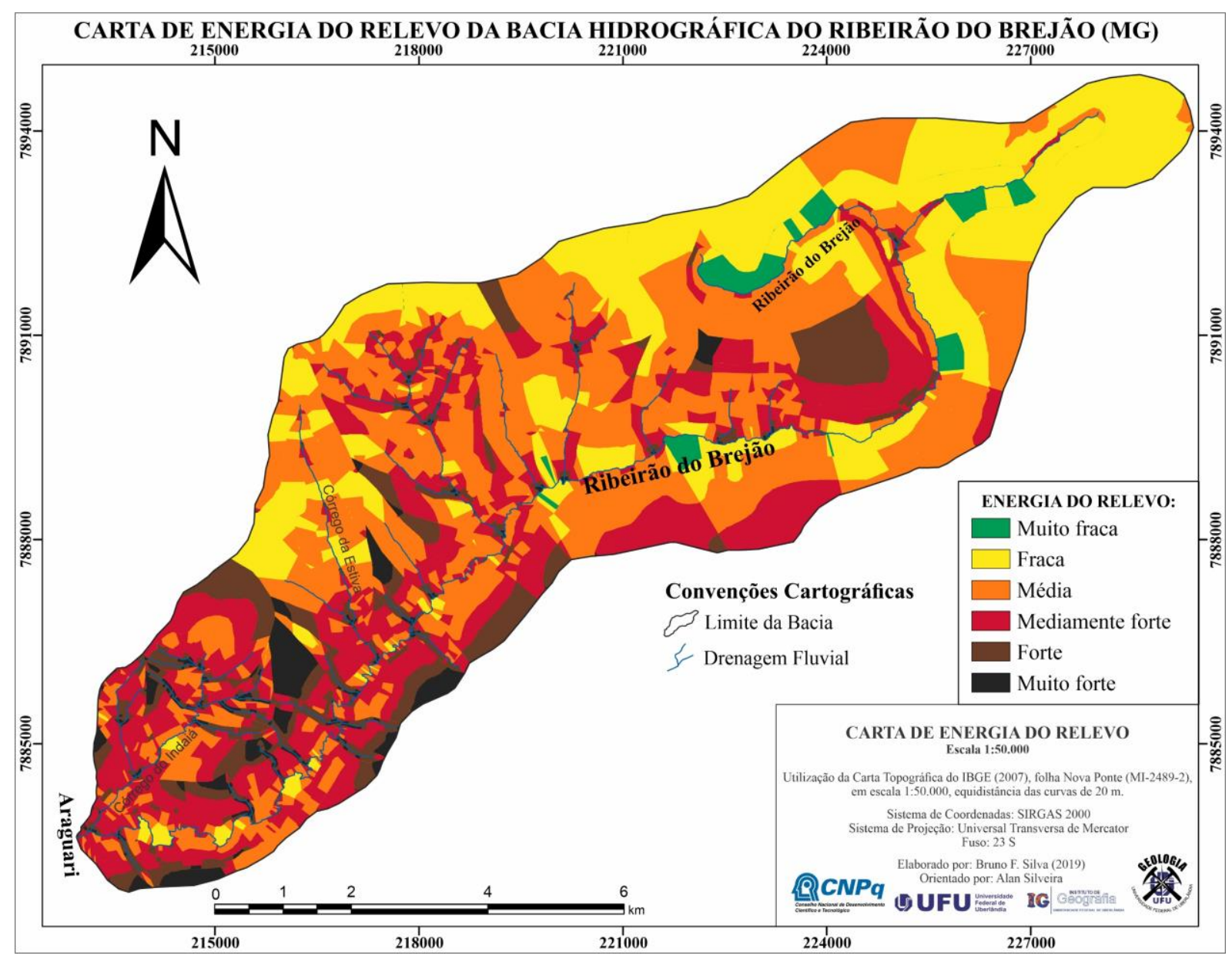

Fonte: Os autores (2020).

Figura 6 - Carta Geomorfológica.

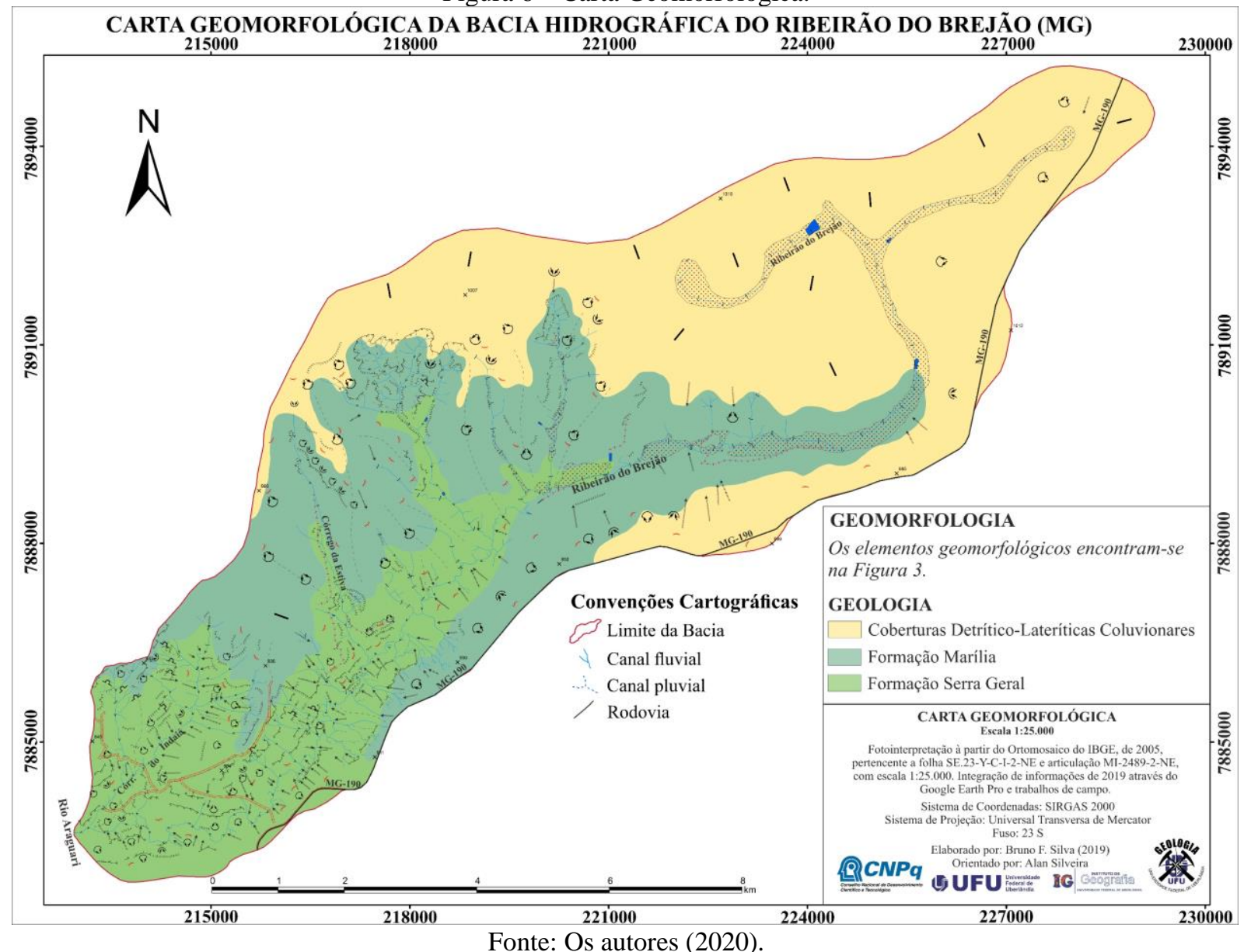


A carta de Energia do Relevo (Figura 5) permite visualizar um comportamento variável da energia ao longo da área de estudo em que há um aumento da potencialidade à ocorrência dos processos morfogenéticos no sentido Baixa Bacia. Em contrapartida, a Alta Bacia e a porção norte/nordeste da Média Bacia possuem classes mais reduzidas, visto que há um distanciamento das bordas dissecadas dos Planaltos e Chapadas da Bacia Sedimentar do Paraná. A partir das características mencionadas, é possível diagnosticar e prever as áreas que serão mais suscetíveis ao desencadeamento dos processos morfogenéticos e às feições erosivas mapeadas na carta Geomorfológica.

A carta Geomorfológica (Figura 6) possibilitou identificar a variação das formas de topos e vertentes ao longo da área de estudo. Na Alta Bacia, tem-se o predomínio de feições tabulares e conforme caminha-se sentido Baixa Bacia, tem-se uma maior ocorrência de feições convexas alternadas por concavidades. A intensificação de feições erosivas e de rupturas topográficas tornam-se acentuadas conforme se dirige para a Baixa Bacia.

Mediante a escala do trabalho e a quantidade de elementos mapeados, houve a necessidade de realizar recortes dos mapeamentos para uma melhor comparação entre as cartas e as condições evidenciadas em campo. Figuras ilustrativas (Figura 7, 8 e 9) foram organizadas para cada setor da área de estudo (Alta, Média e Baixa Bacia), as quais passam a ser apresentadas e discutidas na sequência do texto.

\subsection{Alta Bacia}

A partir da carta de Energia do Relevo é possível notar que a Alta Bacia (Figura 7a) apresenta classes predominantes de fraca a média energia, resultado das reduzidas declividades e densidades de drenagem. Em campo, não foi evidenciado erosões lineares ou exposição de blocos rochosos, mas sim, espessos perfis pedogenizados e lateritizados. Constatou-se uma significativa amplitude dos vales e um reduzido entalhamento que propicia o acúmulo de água e sedimentos em áreas de planícies e terraços fluviais (Aptf) (Figura 7b).

Nesta área, evidenciou-se uma condição de lateritização bem efetiva (Figura 7c e 7d), que pode ser reflexo do rebaixamento do nível d'água, visto que em condições atuais, a água encontra-se em áreas hidromórficas, as quais estão sujeitas ao represamento antrópico (Figura 7e). As vertentes se dirigem ao fundo de vale com reduzidas declividades e dimensões interfluviais, no entanto, o comprimento de rampa é extenso com variação topográfica, fator que elevou a classe de energia do relevo, representado na margem direita do canal fluvial da Figura 7a.

A partir da carta Geomorfológica foi possível evidenciar que a Alta Bacia (Figura 7b) apresenta o predomínio de topos tabulares com reduzidos canais pluviais, vales em fundo plano, extensas áreas de acumulação (Aptf) e forte presença de represamentos (Figura 7e). Assim, tem-se essa área como um ambiente de baixo potencial morfogenético, porém com intensa atuação antrópica já que as áreas de Aptf são utilizadas para o represamento de água destinada ao uso da agricultura (Figura 7e), atividade bastante explorada nos Latossolos Amarelos e Vermelho-Amarelos dos relevos tabulares (Figura 7f). 
Figura 7 - Esquema ilustrativo para a Alta Bacia; (a) recorte da carta de Energia do Relevo para a Alta Bacia (legenda na Figura 5); (b) recorte da carta Geomorfológica para o mesmo setor (legenda na Figura 3); (c) perfil lateritizado; (d) concreções ferruginosas respectivas ao perfil anterior (225.522E, 7.890.680N, UTM23S WGS84); (e) represamento antrópico em Aptf; (f) relevo suavizado bastante utilizado para a agricultura.

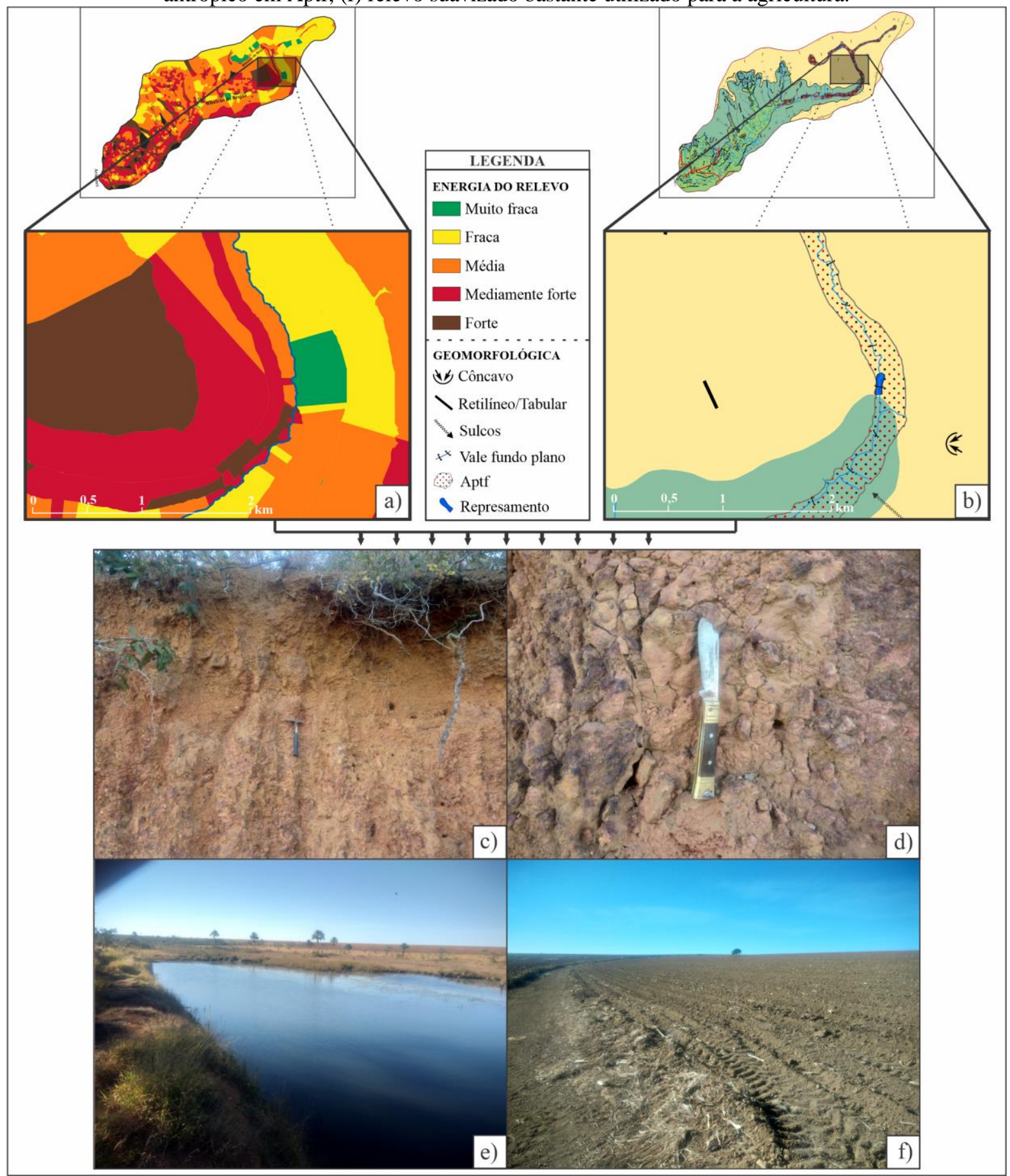

Fonte: Os autores (2020).

\subsection{Média Bacia}

Em relação à energia do relevo, tem-se o predomínio de classe média e mediamente forte, com ocorrência pouco expressiva das classes fraca e forte (Figura 8a). Foi possível identificar uma clara assimetria das vertentes que drenam em direção ao Ribeirão do Brejão, resultando em significativa ocorrência de classes de maior energia nas vertentes à direita do canal principal, como pode ser visto na carta de Energia de Relevo (Figura 5). Assim, as vertentes da margem esquerda apresentam menor potencial à ocorrência dos processos morfodinâmicos, quando comparadas às vertentes da margem direita.

$\mathrm{Na}$ carta Geomorfológica (Figura 8b), observam-se os topos dos interflúvios convexizados e as feições concavizadas nas áreas onde os canais de primeira ordem ou canais pluviais se instalam (Figura 8c). Dominam vales em "V", com ocorrência significativa de canais pluviais entalhados e uma evidente redução de ambientes 
de acumulação (Figura 8b). Os modelados antrópicos se tornam mais intensos devido às proeminentes canalizações e represamentos, já que este setor ainda é utilizado para a agricultura nas porções mais aplainadas (Figura 8d) e, também, por conta do uso de terraceamentos agrícolas, nas vertentes de maiores declividades.

Quanto às notáveis rupturas topográficas (Figura 8b e 8e), as mesmas delimitam os topos aplainados das vertentes dissecadas pelos afluentes do Ribeirão do Brejão. Esse contraste reflete numa configuração dos topos bem latossolizados em relação às rampas sustentadas por cascalheiras e lateritas. Como exemplo, em cota de 941 metros foi identificada a presença de cascalho arenítico da Formação Marília. Conforme subiu-se a vertente, a poucos metros em relação à topografia anterior, o material lateritizado passou a compor a cobertura superficial (Figura 8f).

Figura 8 - Esquema ilustrativo para a Média Bacia; (a) recorte da carta de Energia do Relevo para a Média Bacia (legenda na Figura 5); (b) recorte da carta Geomorfológica para o mesmo setor (legenda na Figura 3); (c) alternância entre convexidade e concavidade das vertentes; (d) solo utilizável para a agricultura mediante suavidade do relevo; (e) ruptura topográfica margeando o canal; (f) litoclastos de arenito e concreções ferruginosas que sustentam a ruptura topográfica local (218.433E, 7.889.978N, UTM23S WGS84).

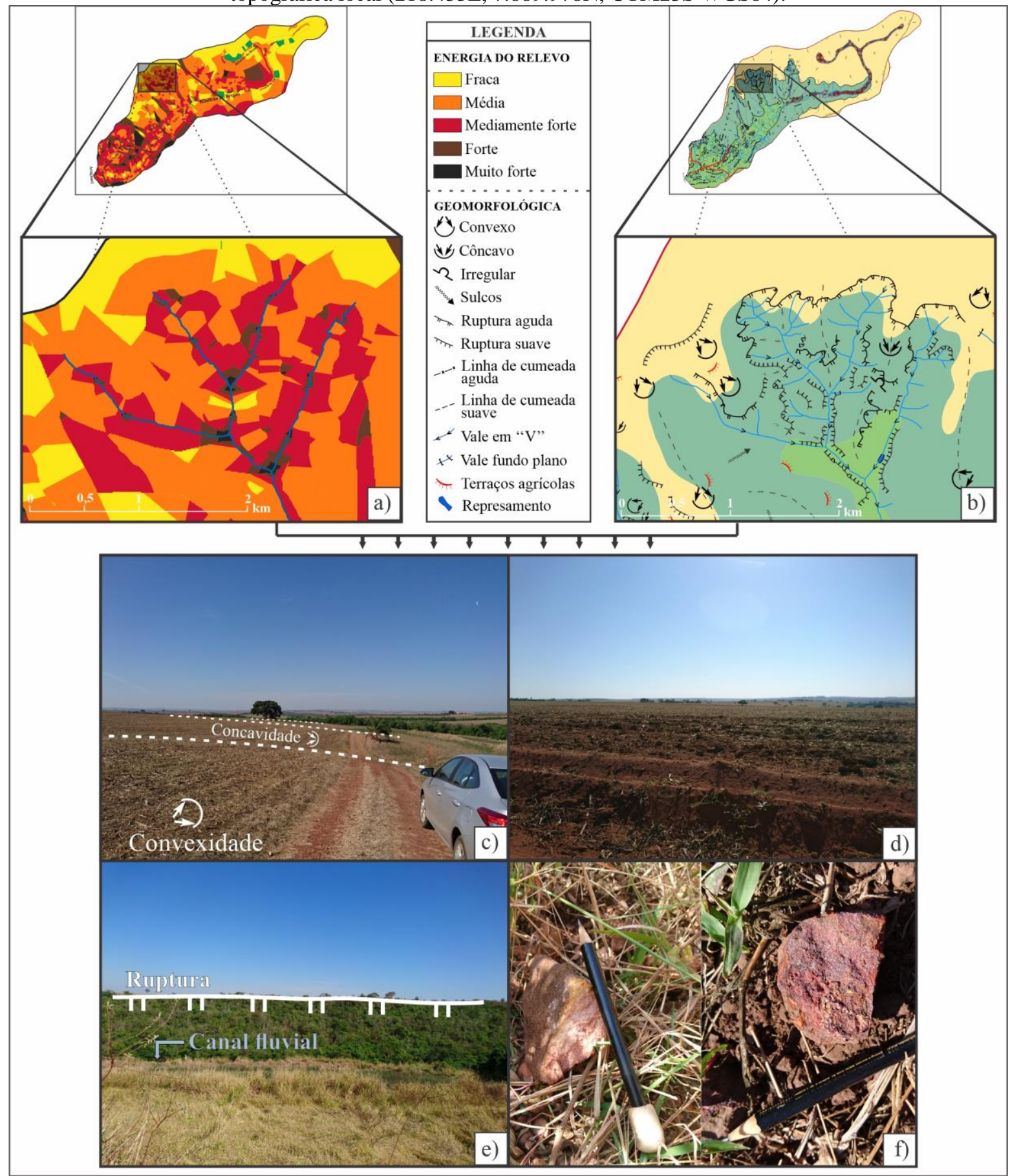

Fonte: Os autores (2020). 


\subsection{Baixa Bacia}

A relação entre elevados valores de declividade, de densidade de drenagem e de entalhamento dos vales propicia a ocorrência de classes forte e muito forte para a energia do relevo, indicando um grande potencial morfogenético nesse setor de estudo (Figura 9a). Conforme registra a carta Geomorfológica (Figura 9b), a Baixa Bacia apresenta vertentes convexas, côncavas e irregulares, sendo as duas últimas mais comuns nas áreas de rupturas topográficas associadas a canais pluviais bem entalhados. Os vales são entalhados em "V" e os ambientes de acumulação são praticamente nulos.

As rupturas do tipo aguda configura os diferentes patamares dos derrames de basalto da Formação Serra Geral. Tem-se inúmeras ocorrências de sulcos que erodem intensamente a cobertura superficial, ressaltando-se, ainda, que os canais pluviais são bem presentes e entalhados neste setor. Devido às feições erosivas e exposições de blocos rochosos, como pode ser visto em campo, esse setor apresenta restrito uso da agricultura, não registrando ocorrências de captação de água e de represamentos. $\mathrm{O}$ uso da água se faz para a dessedentação animal da pecuária extensiva, a qual colabora notadamente para o agravamento da dinâmica erosiva.

O basalto da Formação Serra Geral configura o leito rochoso dos canais entalhados em "V" (Figura 9c), quando por vezes se encaixam nas fraturas preferenciais associadas. Nas vertentes da margem direita do canal principal, de elevada energia do relevo, tem-se a ocorrência de perfis de solo pouco desenvolvidos (Neossolos Regolíticos) compostos por seixos comumente lateritizados, porém com predomínio de quartzos e litoclastos de arenito, possivelmente associados a um material transportado, cuja cota de registro é de 892 metros (Figura 9d). Conforme se dirige à Média Bacia, tem-se uma redução da declividade, quando se evidenciam perfis de lateritas (Figura 9e) que sustentam as áreas dos topos mais aplainados.

Registra-se, por fim, a presença de uma stone line contínua visível ao longo do corte de estrada da MG-190 (Figura 9f), em cotas que variam de $911 \mathrm{~m}$ a 858 m, cujas distâncias horizontais entre estes extremos são de $1,18 \mathrm{~km}$ de rodovia ou 1 (um) km em linha reta. É possível observar que em alguns pontos do regolito a stone line pavimenta os topos dos basaltos, cujos litoclastos são bastante semelhantes com àqueles observados nas rupturas topográficas da Média Bacia, de cota $941 \mathrm{~m}$, bem como aos perfis de solo deste setor, de cota $892 \mathrm{~m}$. Neste sentido, reforça-se tal condição como evidência de um possível material transportado, representando antigas superfícies erosivas.

A partir dos elementos descritos anteriormente para os três setores, a carta de Energia do Relevo possibilitou o zoneamento das áreas mais suscetíveis aos processos morfodinâmicos, em que a Alta Bacia apresenta o predomínio da pedogênese enquanto a Baixa Bacia apresenta a proeminência da morfogênese, que corrobora com as feições destacadas na carta Geomorfológica. Desta forma, tem-se na Alta Bacia uma grande interferência antrópica por conta das atividades agrícolas, visto que esta porção da área de estudo apresenta perfis de solos espessos e fundos de vales pouco entalhados que se constituem em áreas de acumulação, cujo recurso é utilizado para irrigação.

Por outro lado, a Baixa Bacia apresenta baixo potencial para as atividades agrícolas devido à ocorrência de inúmeras feições erosivas lineares, que se intensificam ainda mais por conta da interferência antrópica da pecuária. Por mais que a Alta Bacia apresente erosões mais restritas, é evidente que as atividades antrópicas neste setor propiciam uma alteração na dinâmica natural e intensificam os processos denudativos. Assim, torna-se preocupante que haja um avanço dos processos erosivos em direção à montante, por meio de erosões regressivas ou remontantes, que já atingem porções da Média Alta Bacia. 
Figura 9 - Esquema ilustrativo para a Baixa Bacia; (a) recorte da carta de Energia do Relevo para a Baixa Bacia (legenda na Figura 5); (b) recorte da carta Geomorfológica para o mesmo setor (legenda na Figura 3); (c) basalto proeminente no leito do canal (213.551E, 7.884.222N, UTM23S WGS84); (d) perfil de solo composto por material transportado; (e) horizonte bem lateritizado expresso pelas concreções ferruginosas; (f) Stone line pavimentando os basaltos da Formação Serra Geral (216.703E, 7.884.237N, UTM23S WGS84).

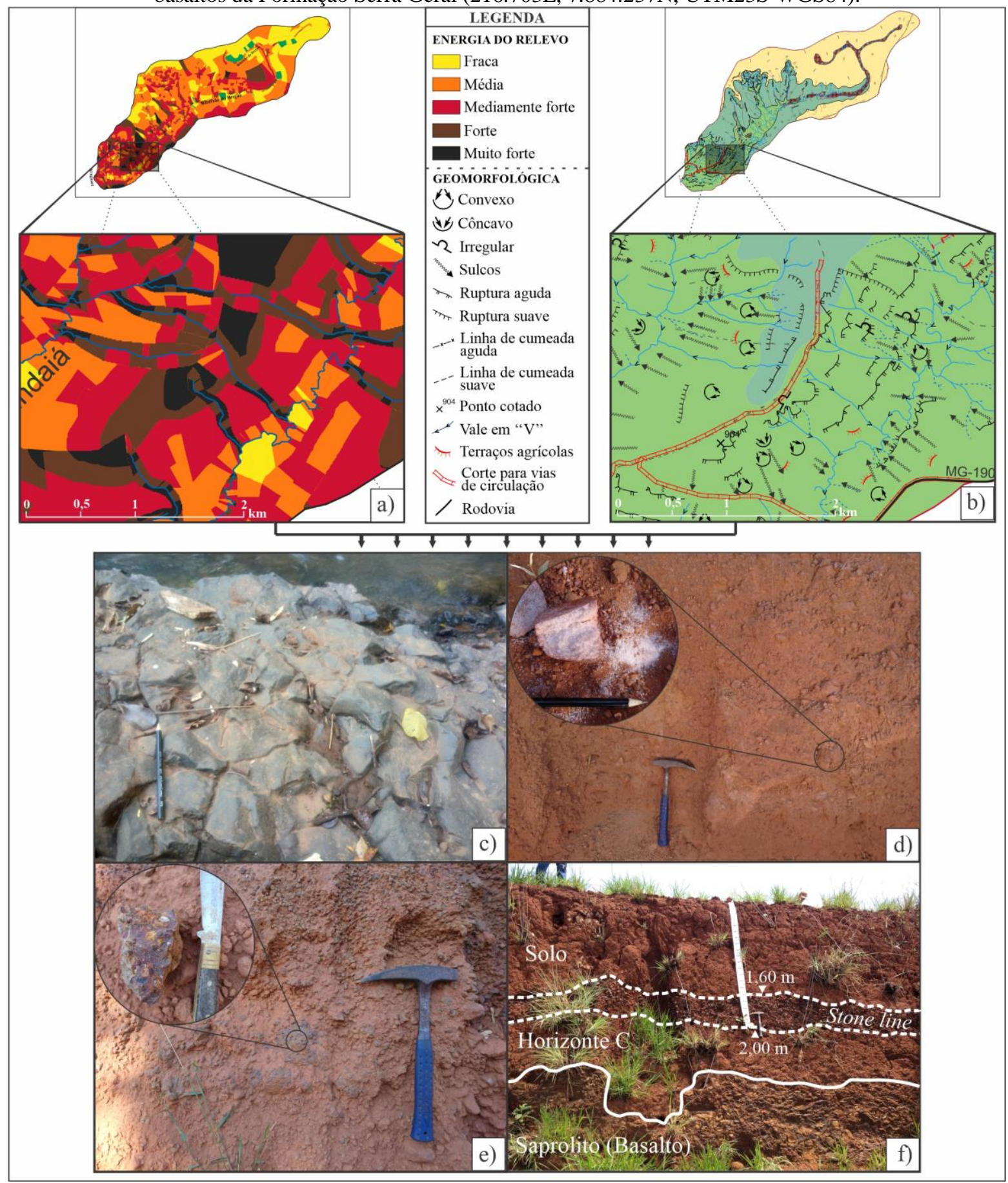

Fonte: Os autores (2020).

\section{CONSIDERAÇÕES FINAIS}

A partir de uma análise da área de estudo, tem-se a ocorrência de inúmeras feições erosivas na Baixa Bacia que tendem a reduzir conforme se dirige no sentido da Alta Bacia, em virtude dos distintos contextos geológico-geomorfológicos. Contudo, há uma intensa interferência antrópica na Alta Bacia que pode proporcionar uma fragilidade na dinâmica natural e, consequentemente, promover uma ascensão das feições erosivas em direção a este setor da área de estudo. A própria evolução das condições de relevo para área denotam essa dinâmica regressiva, tendo em vista que o Ribeirão do Brejão representa um canal fluvial que disseca as bordas das Chapadas do Brasil Central. A Baixa Bacia e parte da Média Bacia representam compartimentos de relevo das bordas erosivas de Chapadas, enquanto o setor de Alta Bacia representa os topos 
aplainados latossolizados e lateritizados de Chapadas.

O posicionamento da área de estudo na borda da Bacia Sedimentar do Paraná e o contexto do soerguimento do Alto Paranaíba podem estar associados a essa dinâmica erosiva na medida em que movimentos positivos ascensionais alteraram os níveis de base, colaborando com o entalhamento dos canais. O material transportado evidenciado ao longo dos perfis de solo e a stone line bem expressiva e contínua ao longo do corte da rodovia reforçam a hipótese de depósitos correlativos que pavimentaram os derrames basálticos da Formação Serra Geral, corroborando em evidências de uma situação paleoclimática associada aos processos pretéritos de aplainamento.

A dinâmica erosiva possibilita um indicativo da evolução da bacia, visto que atribui formas ao relevo. $\mathrm{Na}$ conjuntura atual, tem-se uma condição de clima úmido associado a uma erosão regressiva atuante e expressa pelas rupturas topográficas. Por outro lado, os perfis de alteração encontrados nas rupturas topográficas acusam uma dinâmica erosiva pretérita, em virtude de processos denudativos em porções a montante que permitiram a pavimentação das áreas mais baixas. A referida stone line, representaria depósitos correlativos, porém formados sob a ação de um clima mais seco, com uma morfogênese mecânica ativa.

Deste modo, o uso desses documentos cartográficos possibilita uma compreensão da dinâmica geomorfológica atual, fornecendo dados e produtos para o planejamento territorial/ambiental, bem como colabora com indicativos da evolução geomorfológica da bacia hidrográfica selecionada para estudo.

\section{Agradecimentos}

Os autores agradecem o Conselho Nacional de Desenvolvimento Científico e Tecnológico (CNPq) pela concessão da bolsa referente ao processo $\mathrm{PIBIC/CNPq/UFU} \mathrm{n}{ }^{\circ}$ 02/2018.

\section{Contribuição dos Autores}

O autor Bruno Ferreira da Silva contribuiu com os itens conceptualização, curadoria dos dados, análise formal, aquisição de financiamento, investigação, metodologia, recursos, validação, visualização, redação minuta inicial e redação - revisão e edição. Os autores Alan Silveira e Marília Barbosa contribuíram com a investigação, metodologia, recursos, validação, visualização e redação - revisão e edição, sendo que o primeiro citado colaborou, em adicional, com a conceptualização, aquisição de financiamento e administração do projeto.

\section{Conflitos de interesse}

Os autores declaram que não há conflitos de interesse.

\section{Referências}

ANDRADE, C.E.; CUNHA, C.M.L.; SOUZA, T.A. A cartografia geomorfológica: um exemplo de aplicação no litoral norte do estado de São Paulo. In: VIII Simpósio Nacional de Geomorfologia, III Encontro Latino Americano de Geomorfologia, I Encontro Ibero-Americano de Geomorfologia e I Encontro IberoAmericano do Quaternário, 2010, Recife-PE. Anais... VIII SINAGEO, 2010, p. 1-13.

BASILICI, G.; SGARBI, G.N.; FÜHR, D.B.P.F. A Sub-Bacia Bauru: Um sistema continental entre deserto e cerrado. In: Hasui Y., Carneiro C.D.R., Almeida F.F.M., Bartorelli A. coords. 2012. Geologia do Brasil. São Paulo: Editora Beca, p. 520-543.

BRAUN, O.P.G. Contribuição à geomorfologia do Brasil central. Revista Brasileira de Geografia, Rio de Janeiro, 32(3):3-39, 1971.

CARVALHO, D.T.L.; BUENO, G.T.; JESUS, G.N.; ROSOLEN, V.S. Compartimentação e evolução do relevo da chapada Uberaba-Uberlândia-MG. Os Desafios da Geografia Física na Fronteira do Conhecimento, Campinas: Instituto de Geociências, UNICAMP, 2017, v. 01, p. 5967-5978.

CASSETI, V. Geomorfologia. Goiânia: [S.I.], 2005. Disponível em: 
<http://www.funape.org.br/geomorfologia/>. Acesso em: 19 nov. 2019.

CASSETI, V. Introdução à Geomorfologia. 2007. Disponível em: <http://www.funape.org.br/geomorfologia/cap1/in-dex.php/>. Acesso em: 19 nov. 2019.

CODEMIG - Companhia de Desenvolvimento Econômico de Minas Gerais. Relatório Técnico e Carta Geológica: Folha Nova Ponte (SF.23-Y-C-I), escala 1:100.000, 2017. p. 35.

CUNHA, C.M.L.; QUEIROZ, D.S. A cartografia geomorfológica de detalhe: uma proposta visando a multidisciplinaridade. CLIMEP-Climatologia e Estudos da Paisagem, Rio Claro, 2012, v. 7, n. 1-2, p. 22.

CUNHA, C.M.L.; PINTON, L.G. A cartografia do relevo como subsídio para a análise morfogenética de setor cuestiforme. Mercator, Fortaleza, 2013, v. 12, p. 149-158.

CUNHA, C.M.L; MENDES, I.A.; SANCHEZ, M.C. Técnicas de elaboração, possibilidades e restrições de cartas morfométricas na gestão ambiental. Geografia, Rio Claro, 2003, v. 28, n. 3, p. 415-429.

DE BIASI, M. Cartas de declividade: confecção e utilização. Geomorfologia, São Paulo, 1970, n. 21, p. 8-12.

DE BIASI, M. A Carta Clinográfica: os métodos de representação e sua confecção. Revista do Departamento de Geografia, São Paulo, 1992, n. 6, p. 45-60.

FERREIRA, M.V.; TINÓS, T.M.; PINTON, L.D.G.; CUNHA, C.M.L. A dissecação horizontal como parâmetro morfométrico para avaliação do relevo: proposta de técnica digital automática. Revista Brasileira de Geomorfologia, São Paulo, 2014, v. 15, p. 585-600.

FERREIRA, M.V.; TINÓS, T.M.; PINTON, L.DG.; LUPINACCI, C.M. A cartografia da dissecação vertical para avaliação do relevo: proposta de técnica automática. Revista Brasileira de Cartografia, Rio de Janeiro, 2015, v. 67, n. 6, p. 1231-1245.

HUBP, J.I.L. Elementos de Geomorfologia Aplicada (métodos cartográficos). México: Instituto de Geografia, 1988, 128 p.

KING, L. A geomorfologia do Brasil oriental. Revista Brasileira de Geografia, Rio de Janeiro, 1956, 18(2), 147-265.

MAURO, C.A.; RUSSO, I.L.; BOVO, R.; TELES, A.P.S.S.; CARVALHO, M.B.S.; PICARELLI, A.; MELO, E.M.M. Contribuição ao Planejamento Ambiental de Cosmópolis-SP-BR. In: Encuentro de Geógrafos de América Latina, 3, 1991, Toluca. Memórias. Toluca: UAEM, 1991, v.4, p. 391-419.

MENDES, I.A. A dinâmica erosiva do escoamento pluvial na bacia do Córrego Lafon - Araçatuba-SP. Tese (Doutorado em Geografia) - FFLCH, USP, São Paulo, 1993, v. 1, 192 p.

MILANI, E.J. Comentários sobre a origem e a evolução tectônica da Bacia do Paraná. In: MANTESSO-NETO, V.; BARTORELLI, A.; CARNEIRO, C.D.R.; BRITO-NEVES, B.B.B. (Orgs.), Geologia do continente sul-americano: evolução da obra de Fernando Flávio Marques de Almeida. São Paulo: Beca, 2004, p. 265-291.

MOTTA, P.E.; BARUQUI, A.M.; SANTOS, H.G. Levantamento de reconhecimento de média intensidade dos solos da região do Alto Paranaíba, Minas Gerais. Rio de Janeiro: Embrapa Solos, 2004, 238 p.

NOVAIS, G.T. Caracterização climática da mesorregião do Triangulo Mineiro/Alto Parnaíba e do entorno da Serra da Canastra (MG). Dissertação (Mestrado em Geografia) - Instituto de Geografia, Universidade Federal de Uberlândia (UFU), Uberlândia, 2011, 175 p.

OTTO, J.; GUSTAVSSON, M.; GEILHAUSEN, M. Cartography: design, symbolisation and visualisation of geomorphological maps. In: Developments in Earth Surface Processes. Netherlands: Elsevier, 2011, p. 253-295.

PASCHOAL, L.G.; CONCEIÇÃO, F.T.; CUNHA, C.M.L. Utilização do ArcGis 9.3 na elaboração de simbologias para mapeamentos geomorfológicos: uma aplicação na área do Complexo Argileiro de Santa Gertrudes/SP. 2010. In: VIII Simpósio Nacional de Geomorfologia, 2010, Recife. Anais... Recife: 2010, $13 \mathrm{p}$.

ROSS, J.L.S. Relevo brasileiro: uma nova proposta de classificação. Revista do Departamento de Geografia, 
São Paulo, 1985, v.4, p. 25-39.

ROSS, J.L.S. Geomorfologia: Ambiente e planejamento. São Paulo: Contexto, 1991, 85 p.

SATO, S.E.; LUPINACCI, C.M. Cartografia Geomorfológica de Detalhe. In: SIMON, A.H.; LUPINACCI, C.M. (Org.). A Cartografia Geomorfológica como Instrumento para o Planejamento. Pelotas: Ed. UFPEL, 2019, v. 01, p. 13-21.

SEER, H.J.; MORAES, L.C. Geologia Regional do Triângulo Mineiro. Projeto Triângulo Mineiro. CODEMIG-CPMTC/UFMG, 2017, 123 p.

SILVA, J.M.O.; SILVA, E.V. Planejamento ambiental em uma unidade de conservação no município de Beberibe-Ceará. Geografia Ensino \& Pesquisa, Santa Maria, 2012, v. 16, n. 2, p. 129-146.

SILVA, B.F.; SILVEIRA, A.; BARBOSA, M.I.M. O Grau de Entalhamento da Bacia do Ribeirão Brejão: Aplicação de Técnica Cartográfica Automática para a Identificação de Áreas Suscetíveis aos Processos Morfogenéticos. In: Simpósio Ambiental 2019, Uberlândia. Anais... Uberlândia, v. 2, 2019a, p. 231-238.

SILVA, B.F.; SILVEIRA, A.; BARBOSA, M.I.M. Declividade e características litopedológicas na Bacia do Ribeirão do Brejão: subsídios ao Zoneamento Ambiental Produtivo. In: Simpósio de Ciências Agrárias e Ambientais, 2019, Monte Carmelo (MG). Anais... Monte Carmelo, 2019b., p. 1-4.

SILVEIRA, A.; CUNHA, C.M.L. A Energia do Relevo como variável morfométrica para a identificação da fragilidade natural: contribuição para ambiente de expansão urbana. In: $13^{\circ}$ Congresso Brasileiro de Geologia de Engenharia e Ambiental, 2011, São Paulo. Anais... São Paulo, 2011. p. 01-10.

SILVEIRA, A.; CUNHA, C.M.L. Morfometria do relevo e ocupação urbana: contribuição ao planejamento. In: XV Simpósio Brasileiro de Geografia Física Aplicada (SBGFA), 2013, Vitória. Anais... Vitória, 2013, p. 191-200.

SILVEIRA, P.B.; LUPINACCI, C.M. A cartografia geomorfológica de detalhe como subsidio ao planejamento territorial: o caso da bacia do ribeirão Alam Grei -SP. Os Desafios da Geografia Física na Fronteira do Conhecimento, 2017, v. 1, p. 5931-5942.

SPIRIDONOV, A.I. Princípios de la metodologia de las investigaciones de campo y el mapeo geomorfológico. 1981. 657 p. Dissertação (Mestrado em Geografia) - Havana: Universidad de la Havana, Faculdad de Geografia. 1981.

TRICART, J. Principes et méthodes de la Géomorphologie. Paris: Masson et Cie, 1965, 496 p.

VALADÃO, R.C. Geodinâmica de superfícies de aplanamento, desnudação continental e tectônica ativa como condicionantes da megageomorfologia do Brasil oriental. Revista Brasileira de Geomorfologia, Brasília, 2009, v. 10, n. 2, p. 77-90.

VERSTAPPEN, H.T. Old and new trends in geomorphological and landform mapping. In: SMITH, M.J.; PARON, P; GRIFFITHS, J.S. Geomorphological mapping: methods and applications. Developments in earth surface processes. Netherlands: Elsevier - Developments in earth surface processes, 2011. p. 1338.

VERSTAPPEN, H.T.; ZUIDAM, R.A. ITC system of geomorphological survey. Netherlands: ITC, 1975, $3^{\text {a }}$ ed., $49 \mathrm{p}$.

\section{Biografia do autor principal}

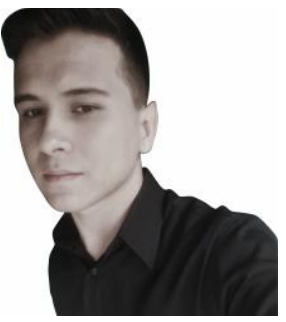

Bruno Ferreira da Silva nasceu em Itumbiara (GO), Brasil, no ano de 1998. Graduação em andamento em Geologia pela Universidade Federal de Uberlândia e é atualmente bolsista do CNPq/UFU (2020-2021) com pesquisas na região do Triângulo Mineiro/Alto Paranaíba, sobretudo nas áreas de Caracterização Geomorfológica, Geológica e Pedológica. 